\title{
PERFEKSIONISME MALADAPTIF DAN PRESTASI AKADEMIK PADA MAHASISWA BERBAKAT INTELEKTUAL: SUATU PENDEKATAN RISET CAMPURAN SEKUENSIAL
}

\author{
Fitriani Yustikasari Lubis ${ }^{1}$, Lydia Freyani Hawadi², Rose Mini Agoes Salim $^{3}$, R. Urip \\ Purwono 4 \\ 1,2,3 Universitas Indonesia \\ Jalan Margona Raya, Kota Depok, Jawa Barat 164242 \\ ${ }^{4}$ Universitas Padjadjaran \\ Jalan Raya Bandung Sumedang KM. 21, Kabupaten Sumedang, Jawa Barat 45363
}

E-mail: fitriani.y.lubis@gmail.com

\begin{abstract}
ABSTRAK
Penelitian ini bertujuan untuk menjelaskan hubungan antara perfeksionisme maladaptif dengan prestasi akademik pada mahasiswa berbakat intelektual. Delapan puluh enam mahasiswa berbakat intelektual yang diperoleh dari proses penjaringan dan penyaringan dari tiga Perguruan Tinggi Negeri terlibat sebagai subjek penelitian dalam studi kuantitatif. Kemudian, 8 mahasiswa berbakat intelektual dipilih dari hasil ekstrem studi kuantitatif sebagai subjek penelitian dalam studi kualitatif. Rancangan penelitian menggunakan pendekatan penelitian campuran sekuensial dengan studi kuantitatif mendahului studi kualitatif. Pengambilan data kuantitatif dilakukan dengan metode survei menggunakan Frost Multidimensional Perfectionism Scale dan self-report nilai IPK. Data yang diperoleh diolah menggunakan uji regresi. Pengambilan data kualitatif dilakukan mengunakan wawancara semiterstruktur dan diolah menggunakan analisis tematik. Hasil penelitian menunjukkan bahwa perfeksionisme maladaptif memiliki pengaruh negatif terhadap prestasi akademik. Hasil riset juga menemukan dinamika yang terjadi antara kedua variabel pada mahasiswa berbakat intelektual berbeda dengan mahasiswa pada umumnya.
\end{abstract}

Kata kunci: perfeksionisme; prestasi akademik; mahasiswa berbakat intelektual; penelitian campuran sekuensial

\section{MALADAPTIVE PERFECTIONISM AND ACADEMIC ACHIEVEMENT IN GIFTED UNDERGRADUATE STUDENT: A MIXED-METHODS STUDY}

\begin{abstract}
This study aims to explain the relationship between maladaptive perfectionism and academic achievement in undergraduate gifted students. Eighty-six undergraduate gifted students selected from the screening and selection process from three State Universities involved in quantitative studies. Then eight undergraduate gifted students were selected from the extreme results of quantitative study to engage in qualitative research. The research design uses an explanatory sequential mixed methods approach with quantitative study preceding qualitative study. Quantitative data was collected by survey method using the Frost Multidimensional Perfectionism Scale and self-report GPA score. The data obtained were analyzed using a regression test. The qualitative data collection was carried out using semi-structured interviews and processed using thematic analysis. The results showed maladaptive perfectionism had
\end{abstract}


a negative influence on academic achievement. The dynamics that occur between the two variables is different in undergraduate gifted student than undergraduate non-gifted student.

Keywords: perfectionism; academic achievement; undergraduate gifted student; explanatory sequential mixed methods

\section{PENDAHULUAN}

Mahasiswa berbakat intelektual merupakan student with special needs sebagai konsekuensi dari karakteristik khas yang mereka miliki (Davis, Rimm, \& Siegle, 2014; Ormrod, Anderman, \& Anderman, 2017). Steiner \& Carr (2003) mengatakan kemampuan yang menjadi karakteristik khas siswa berbakat intelektual sehingga tergolong dalam student with special needs adalah kemampuan kognisi yang berkembang di atas rata-rata, mahasiswa berbakat intelektual memiliki dasar pengetahuan yang lebih luas, menyukai situasi kompleks dan lebih menantang, lebih cepat, dan kaya strategi dalam menyelesaikan masalah, serta memiliki metakognisi yang lebih baik dibandingkan dengan mahasiswa pada umumnya. Perkembangan kemampuan kognisi yang di atas rata-rata kemudian memiliki konsekuensi pada kemampuan sosial-emosi yang khas pada siswa berbakat intelektual. Seringkali kemampuan kognisi yang menonjol secara signifikan ini membuat fokus penanganan siswa berbakat intelektual tertuju pada pengembangan kognisinya. Padahal, para ahli keberbakatan berargumen bahwa fokus pada intelegensi akan membuat siswa berbakat intelektual dari kelompok minoritas atau kondisi ekonomi yang tidak menguntungkan dapat tidak terjaring dalam proses identifikasi (Davis dkk., 2014; Gallagher, 2015).

Renzulli memiliki pandangan yang sama tentang intelegensi bukanlah satu-satunya kriteria untuk mendefinisikan siswa berbakat intelektual. Dalam konsepnya The Three-Ring Renzulli menjelaskan bahwa keberbakatan direfleksikan oleh interaksi antara tiga kriteria, yaitu (1) kemampuan berpikir yang berada di atas rata-rata, (2) komitmen tugas (task commitment/motivasi) yang tinggi, dan (3) kreativitas yang tinggi (Renzulli \& Reis, 1985). Keseimbangan irisan tiga kriteria itu penting karena tidak ada kriteria tunggal atau unikriteria yang dapat menjelaskan keberbakatan. Kriteria komitmen tugas dan kreativitas bukan merupakan pelengkap, namun merupakan kriteria yang sejajar satu sama lain dan memiliki peran sama penting untuk terwujudnya keberbakatan seseorang. Konsep The Three-Ring Renzulli ini juga menjadi acuan batasan keberbakatan yang digunakan di Indonesia dan dalam penelitian ini.

Berbeda dengan mahasiswa pada umumnya, perfeksionisme merupakan salah satu karakteristik yang dominan pada mahasiswa berbakat intelektual, sekitar
$75 \%$ hingga $87,5 \%$ mahasiswa berbakat intelektual menunjukkan kecenderungan untuk perfeksionis (Chan, 2010; Davis dkk., 2014; Schuler, 2000). Callard-Szulgit (2012) mengatakan perfeksionisme mahasiswa berbakat intelektual berasal dari diri sendiri (self-induced) dan hasil belajar dari lingkungannya. Kerr (2009) juga menyatakan pendapat yang sama serta mengatakan interaksi dengan lingkungan yang terjadi sejak masa anak-anak sampai remaja, kemudian interaksi itu menentukan perfeksionisme yang diadopsi oleh mahasiswa berbakat intelektual.

Pada tahun 1960-an, perfeksionisme berawal dari pengamatan klinis sebagai unidimensional yang condong memandang perfeksionisme sebagai patologis (Stoeber, 2018). Dalam dua dekade terakhir, berkembang pandangan multidimensional perfeksionisme yang dipelopori oleh Hamachek pada tahun 1978 sebagai perfeksionisme normal dan neurotik (Stoeber, 2018). Hamachek menjelaskan perfeksionisme normal sebagai perilaku berjuang mengerjakan suatu tugas dengan sempurna dan ketika mencapai keberhasilan akan memunculkan rasa puas pada pencapaian dirinya. Sementara itu, perfeksionisme neurotik sebagai perilaku untuk berjuang mengerjakan suatu tugas dengan sempurna, namun tidak mendatangkan rasa puas karena perfeksionis neurotik selalu mempersepsi hasil yang dicapai tidak cukup baik jika dilihat dari pandangan orang lain (Stoeber, 2018).

Frost, Marten, Lahart, dan Rosenblate (1990) mendukung pendapat Hamacheck dengan menjelaskan bahwa perfeksionis sebagai normal/adaptif dan neurotik/maladaptif. Perfeksionisme sendiri didefinisikan sebagai standar diri yang tinggi sebagai suatu keharusan untuk mencapai hasil yang sempurna, dan menjadi masalah jika diikuti dengan evaluasi diri yang kritis (Frost dkk., 1990). Perfeksionisme adaptif adalah tingkah laku untuk standar diri yang tinggi, sementara perfeksionisme maladaptif adalah tingkah laku untuk standar diri yang tinggi yang didasari oleh ketakutan untuk melakukan kesalahan, keraguan bertindak dan tuntutan, serta kritik dari orangtua, seringkali standar diri ini sangat tinggi sehingga sulit untuk dicapai (Frost dkk., 1990). Dalam perkembangannya, Stoeber (2018) mengatakan bahwa tuntutan dan kritik orangtua merupakan faktor eksternal sebagai penyebab. Sehingga, perfeksionisme maladaptif dalam konsep Frost lebih tepat dijelaskan oleh penetapan standar diri yang tinggi dan disertai evaluasi diri yang 
kritis didasari oleh ketakutan untuk melakukan kesalahan dan keraguan bertindak.

Berikutnya akan dijelaskan hubungan perfeksionisme dengan prestasi akademik pada mahasiswa berbakat intelektual. Pada bagian sebelumnya, dijelaskan bahwa intelegensi yang berkembang lebih baik dibandingkan mahasiswa lainnya merupakan kekhasan utama dari mahasiswa berbakat intelektual. Tinjauan ilmiah berasumsi bahwa dengan kemampuan ini, semua mahasiswa berbakat intelektual akan mencapai prestasi akademik yang tinggi tanpa masalah. Kenyataannya, tidak semua mahasiswa berbakat intelektual mencapai prestasi akademik yang tinggi. Sternberg, Jarvin, dan Grigorenko (2011) dalam bukunya Exploration of Giftedness memberikan analogi terkait fenomena keberhasilan individu berbakat dengan menceritakan tentang William James dan William James Sidis yang keduanya merupakan individu berbakat. William James adalah seorang berbakat yang kemudian menjadi salah satu filsuf dan psikolog yang terkenal pada eranya. Sementara itu, William James Sidis adalah seorang berbakat yang memiliki awal hidup yang luar biasa, namun kemudian menjadi getir dan menarik diri dari ilmu matematika yang merupakan bakatnya. William James Sidis diibaratkan " $a$ bright flame that was extinguished early" (Sternberg dkk., 2011). Fenomena ini umum terjadi pada individu berbakat dan permasalahan utama bukanlah terletak pada kemampuan intelektualnya.

Penelitian Terman dan Oden (1959) terhadap 150 individu berbakat yang sukses dan 150 individu berbakat yang kurang sukses dilakukan untuk menemukan kunci kesuksesan pada individu berbakat. Penelitian Terman dan Oden menemukan bahwa bukan taraf kecerdasan yang menjadi pembeda antara sukses dan kurang sukses, namun aspek nonintelektual yang menjadi pembeda. Secara garis besar, hal yang membedakannya adalah penyesuaian sosial-emosi dan dorongan untuk berprestasi (Sternberg \& Davidson, 2005). Rimm (2006) mengatakan pada mahasiswa berbakat intelektual dengan prestasi akademik yang rendah bahwa faktor sosial emosi memegang peranan yang penting. VanTassel-Baska, Cross, dan Olenchak (2009) mengatakan pendapat yang serupa bahwa masalah sosial emosi yang umumnya dihadapi oleh siswa berbakat intelektual dalam tahap perkembangan mereka menuju dewasa adalah perfeksionisme, mengembangkan hubungan yang bermakna, mengatasi sensitivitas dirinya, mengimplementasikan kepedulian sosial dalam tugas atau pekerjaannya, dan menghilangkan perasaan tidak mampu, sehingga mereka membutuhkan bantuan untuk menghadapi masalah sosial emosi dalam tahap perkembangan mereka menuju dewasa awal untuk dapat menampilkan kemampuannya secara optimal. Berdasarkan kajian literatur, diketahui bahwa perfeksionisme merupakan sumber yang berperan dalam masalah sosial emosi yang umum dihadapi oleh siswa berbakat intelektual (Amanda, Siaputra, \& Lasmono, 2012; Ananda \& Mastuti, 2013; Gunawinata, Nanik, \& Lasmono, 2008; Hébert, 2011; Kerr, 2009; Neihart, Reis, Robinson, \& Moon, 2002; Sirois, Monforton, \& Simpson, 2010).

Penelitian yang menerangkan hubungan perfeksionisme dengan kesulitan sosial emosi siswa berbakat intelektual dapat dilihat pada kesulitan siswa berbakat intelektual untuk mengambil keputusan atau melakukan suatu aksi ketika mereka merasa dirinya tidak mampu memberikan yang sempurna. Sementara itu, dalam mengimplementasikan kepedulian sosial dalam tugas atau pekerjaannya, sifat perfeksionisme dapat menghambat mereka untuk benar-benar merealisasikan atau menyelesaikan tugas dan pekerjaannya tersebut, terutama saat mereka merasa dirinya tidak mampu memenuhi standar yang diharapkan. Perfeksionisme dapat menyebabkan munculnya perilaku yang menghambat siswa berbakat intelektual untuk berprestasi, misalnya ketakutan untuk melakukan kesalahan dan kegagalan, kesulitan untuk membuat keputusan, prokrastinasi, dan low self-esteem (Cross \& Cross, 2015; Eklund, Tanner, Stoll, \& Anway, 2015; Stornelli, Flett, \& Hewitt, 2009). Ketika perfeksionisme mendominasi masalah sosial emosi siswa berbakat intelektual, maka siswa akan sulit untuk memfokuskan dirinya pada upaya optimalisasi potensi bidang akademik. Hal ini sejalan dengan penelitian-penelitian terbaru mengenai otak yang menemukan bahwa faktor afektif yang mengelola emosi mendahului kognisi, dan bukan sebaliknya (VanTassel-Baska dkk., 2009).

Dalam konteks pendidikan formal, keberhasilan mahasiswa berbakat intelektual dilihat dari pencapaian prestasi akademik di perguruan tinggi. Prestasi akademik adalah hasil penilaian capaian pembelajaran lulusan pada akhir program studi yang dinyatakan dengan Indeks Prestasi Kumulatif (IPK), mengacu pada. Peraturan Menteri Pendidikan dan Kebudayaan Republik Indonesia Nomor 3 Tahun 2020 tentang Standar Nasional Pendidikan Tinggi pasal 26 ayat 5 dan ayat 7. Beberapa penelitian menggunakan Indeks Prestasi Kumulatif (IPK) untuk merepresentasikan prestasi akademik dalam konteks pendidikan tinggi (Blankstein, Dunkley, \& Wilson, 2008; Brumbaugh, Lepsik, \& Olinger, 2007; Elion, Wang, Slaney, \& French, 2012; Madigan, 2019; Nounopoulos, Ashby, \& Gilman, 2006). Oleh karena itu, mengacu pada kemampuan intelektual yang dimiliki, diharapkan mahasiswa berbakat intelektual dapat mencapai IPK dengan kategori pujian sebagai hasil belajar tertinggi di perguruan tinggi.

Penelitian ini menjelaskan aspek nonintelektual yang memengaruhi terhambatnya keberhasilan akademik pada mahasiswa berbakat intelektual, khususnya terkait perfeksionisme maladaptif. Perfeksionisme maladaptif yang menetap di masa dewasa dapat menjadi salah satu 
penyebab gagalnya mahasiswa berbakat intelektual menunjukkan kontribusi prestasi secara nyata. Analogi yang dijelaskan tentang William James Sidis dan William James menunjukkan prestasi yang terkendala lebih jelas terlihat di masa dewasa, bahkan dapat mengarahkan pada suicidal ideation (Fong \& Yuen, 2014; Sternberg dkk., 2011). Oleh karena itu, penelitian keberhasilan mahasiswa berbakat intelektual pada tingkat pendidikan perguruan tinggi yang menjadi fokus

\section{METODE}

Penelitian ini menggunakan pendekatan riset campuran tipe explanatory sequential design (Creswell \& Clark, 2011). Pendekatan dipilih dengan pertimbangan hasil yang diperoleh dari tahap studi kuantitatif dapat dijelaskan dengan lebih rinci oleh hasil yang diperoleh dari tahap studi kualitatif.

Pada tahap studi kuantitatif, teknik pengambilan sampel yang digunakan adalah non-probability sampling dengan jenis purposive sampling, di mana sampel dengan sengaja dipilih sesuai kebutuhan dan tujuan penelitian dan subjek penelitian tidak diambil secara acak (Creswell \& Clark, 2011). Karakteristik responden yang digunakan dalam penelitian ini adalah sebagai berikut:

1) Mahasiswa berbakat intelektual berdasarkan konsep The Three-Ring Renzulli yaitu: (a) IQ di atas rata-rata (IQ $>125)$, (b) taraf kreatif CQ $>110$ (kategori tinggi), dan (c) taraf komitmen tugas (task commitment) TC > 130 (kategori tinggi). Nilai IQ diperoleh berdasarkan penjelasan Renzulli (1986) bahwa IQ siswa berbakat intelektual berada dalam persentil $95 \%$ yang berarti dalam penggunaan skala IQ TIKI-T setara dengan $125 \mathrm{ke}$ atas. Penetapan nilai IQ akan merepresentasikan keberbakatan dengan syarat didampingi dengan kreativitas yang tergolong tinggi dan komitmen tugas yang tergolong tinggi;

2) Mahasiswa aktif di program studi dengan passing grade masuk yang tinggi di Perguruan Tinggi Negeri (PTN) terakreditasi;

3) Usia 18-21 tahun, dengan pertimbangan mahasiswa termasuk pada tahap dewasa awal. Pada tahap dewasa awal, perfeksionisme dan selfcompassion yang dimiliki oleh mahasiswa berbakat intelektual telah berkembang dan cenderung menetap.

Penetapan mahasiswa berbakat intelektual diperoleh melalui proses penjaringan dan penyaringan (Renzulli, 1986). Pada tahap penjaringan yang dilakukan, pencarian data berasal dari (1) fakultas melalui surat permohonan izin penelitian dari Fakultas Psikologi UI dan (2) mahasiswa melalui penyebaran Google Form untuk diisi tentang data diri. Berdasarkan pengumpulan data subjek penelitian, diperoleh 1656 data mahasiswa yang memiliki penelitian. Pertanyaan penelitian pada penelitian ini adalah "Apakah perfeksionisme maladaptif berpengaruh negatif terhadap prestasi akademik pada mahasiswa berbakat intelektual?" Kemudian dari penelitian ini ingin diketahui juga bagaimana perfeksionisme maladaptif memengaruhi prestasi akademik secara negatif pada mahasiswa berbakat intelektual. Pendekatan penelitian campuran dianggap yang paling sesuai untuk dapat menjawab pertanyaan penelitian ini.

IQ di atas 130 dan/atau merupakan alumni program akselerasi. Tim peneliti berhasil memperoleh nomor kontak 801 mahasiswa, sementara 855 lainnya tidak berhasil dihubungi karena tidak ada nomor kontaknya. 589 mahasiswa yang dikontak tidak merespon atau menolak untuk ikut serta dengan alasan sibuk. 212 mahasiswa menyatakan kesediaannya untuk mengikuti tahap penyaringan dan penelitian yang dilakukan.

Tahap penyaringan dilakukan melalui pemeriksaan psikologi oleh peneliti dan asisten peneliti dengan kualifikasi mahasiswa psikologi minimal sudah berada pada tingkat akhir. Proses identifikasi pada tahap penyaringan menggunakan alat tes TIKI-T pendek, Tes Kreativitas Verbal (TKV, Utami Munandar) dan alat ukur Task Commitment (SKALA TC-RENDI 03, Hawadi) dengan kriteria kelulusan sesuai dengan konsep The Three-Ring Renzulli. Setelah dilakukan pengolahan dan interpretasi terhadap pemeriksaan psikologi yang dilakukan, 95 mahasiswa yang memenuhi konsep The Three-Ring Renzulli diikutsertakan dalam penelitian. Hanya saja, 9 mahasiswa tidak memberikan data yang lengkap terkait prestasi akademik sehingga pada penelitian ini responden terdiri dari 86 orang.

Perfeksionisme maladaptif diukur menggunakan Frost Multidimensional Perfectionism Scale (FMPS, 1990) yang telah diadaptasi dalam bahasa Indonesia, terdiri dari dimensi standar diri (personal standard), ketakutan terhadap kesalahan (concern over mistakes), dan keraguan dalam bertindak (doubt over action). Reliabilitas FPMS, yaitu 0,821 untuk dimensi ketakutan terhadap kesalahan (the concern over mistakes), 0,731 untuk dimensi standar personal (personal standards), dan 0,720 untuk dimensi keraguan untuk bertindak (doubts about action). Validitas FMPS dilakukan melalui uji confirmatory factor analysis (CFA) dan diperoleh $p$ value chi-square 1,00 dan RMSEA 0,000, serta semua item memiliki loading factor $>0,2$, sehingga model pengukuran yang diperoleh dari data telah sesuai dengan teori yang digunakan.

Prestasi akademik diperoleh dari skor Indeks Prestasi Kumulatif (IPK) yang dilaporkan sendiri oleh mahasiswa berbakat intelektual dari IPK terakhir pada saat penelitian berlangsung. Proses pengolahan data, baik data demografik maupun data survei, dilakukan dengan bantuan software IBM SPSS 21.0 for Windows. Sementara itu, uji statistik dalam penelitian ini menggunakan analisis regresi dengan perfeksionisme 
maladaptif sebagai variabel prediktor dan prestasi akademik sebagai variabel dependen. Hal ini dilakukan untuk melihat besaran peranan variabel bebas terhadap varibel terikat.

Studi tahap kualitatif dilakukan dengan menggunakan metode wawancara semiterstruktur terhadap 8 orang mahasiswa berbakat intelektual yang dipilih dari responden yang memiliki nilai ekstrem tinggi dan rendah untuk perfeksionisme dan prestasi akademik pada tahap studi kuantitatif. Pemilihan responden kualitatif dengan nilai ekstrem tinggi dan rendah dilakukan untuk memperoleh persamaan dan perbedaan tema antara kedua kelompok. Analisis data kualitatif diawali dengan mengembangkan makna umum dari data, kemudian melakukan coding terhadap deskripsi dan tema-tema tentang inti fenomena (Creswell, 2007), dan diakhiri dengan melakukan proses penarikan kesimpulan atau verifikasi.

\section{HASIL DAN PEMBAHASAN}

Subjek pada tahap studi kuantitatif berjumlah 86 orang mahasiswa berbakat intelektual. Subjek penelitian perempuan lebih banyak dari laki-laki. Rentang usia terdiri dari 17-22 tahun, dengan proporsi yang tidak merata (rata-rata usia $19,77, \mathrm{SD}=1,43$ ). Responden paling banyak merupakan anak pertama $(54,7 \%)$. Jurusan tempat kuliah responden didominasi oleh rumpun ilmu sains dan teknologi dibandingkan dengan kedua rumpun lainnya, yaitu ilmu kesehatan dan ilmu sosial dan humaniora.

Sebelum melakukan uji regresi, peneliti melakukan preliminary analysis untuk perhitungan uji normalitas, linearitas, dan korelasi sebagai syarat melakukan analisis regresi. Hasil dari perhitungan menunjukkan bahwa alat ukur Frost Multidimensional Perfectionism Scale (FMPS) terbukti normal, sementara pada self-report IPK ditemukan data outlier yang dapat mempengaruhi hasil analisis. Setelah dilakukan pengujian distribusi data, ditemukan nilai skewness yang lebih dari 1,96 sehingga self-report IPK tidak berdistribusi normal.

Data responden yang diambil dari mahasiswa berbakat intelektual umumnya memiliki IPK yang tinggi, sehingga terjadi pengelompokkan pada nilai IPK tertentu yang secara teori dapat diterima. Meskipun demikian, asumsi distribusi normal perlu dipenuhi untuk dapat dilakukan pengujian analisis utama. Oleh karena itu, dilakukan pengubahan skor outlier dengan nilai mean ditambah dua SD untuk membuat variabel IPK berdistribusi normal dilihat dari nilai skewness tanpa mengubah makna skor yang ada (Field, 2009). Setelah dilakukan modifikasi terhadap IPK, kedua variabel memiliki deskripsi statistik seperti pada Tabel 1 berikut.

Tabel 1. Deskripsi Stastistik untuk Variabel

\begin{tabular}{llllll}
\hline Alat Ukur & Mean & SD & Min & Max & Skewness \\
\hline FMPS(CM,D,PS) & 66,47 & 11,58 & 33 & 99 & .256
\end{tabular}

\begin{tabular}{llllll} 
IPK & 3,41 & 0,34 & 2,66 & 4.11 & $-0,120$ \\
\hline
\end{tabular}

Berdasarkan hasil uji linearitas, kedua variabel memiliki hubungan yang linier dan memiliki hubungan negatif yang signifikan $(p>0,1)$. Oleh karena itu, data dalam penelitian ini memenuhi syarat untuk dilakukan analisis regresi. Berikut Tabel 2 yang menunjukkan hasil dari analisis regresi pada penelitian ini.

Tabel 2. Hasil Uji Regresi

\begin{tabular}{llll}
\hline $\mathbf{R}$ & R square & R square change & Sig \\
\hline$-0,207$ & 0,043 & 0,31 & 0,056 \\
\hline
\end{tabular}

Pada penelitian ini, ditemukan korelasi negatif antara perfeksionisme maladaptif dan prestasi akademik $(\mathrm{R}=$ $0,207, p<0,1)$. Semakin tinggi perfeksionisme maladaptif mahasiswa berbakat intelektual, semakin rendah prestasi akademik yang diraih. Hasil ini sejalan dengan hasil penelitian sebelumnya yang menemukan bahwa perfeksionisme maladaptif memiliki pengaruh negatif terhadap prestasi akademik seseorang (Blankstein dkk., 2008; Elion dkk., 2012; Madigan, 2019; Nounopoulos dkk., 2006).

Madigan (2019) melakukan penelitian metaanalisis terhadap hubungan perfeksionisme dan prestasi akademik. Berdasarkan kajian terhadap 37 penelitian dengan 8.901 responden, ditemukan bahwa terdapat hubungan yang kompleks antara perfeksionisme dan prestasi akademik, dengan perfeksionisme adaptif membantu pencapaian akademik dan perfeksionisme maladaptif mengganggu pencapaian prestasi akademik seseorang. Hasil penelitian yang diperoleh sejalan dengan hasil metaanalisis, yaitu perfeksionisme maladaptif mengganggu prestasi akademik, dibuktikan dengan pengaruh negatif yang diberikan oleh perfeksionisme maladaptif.

Berbeda dengan temuan pada penelitian sebelumnya oleh Brumbaugh dkk. (2007), di mana dinyatakan bahwa tidak terdapat hubungan yang signifikan antara perfeksionisme dan prestasi akademik, baik untuk perfeksionisme adaptif maupun maladaptif. Serupa dengan penelitian ini, penelitian Brumbaugh dkk. (2007) juga melihat hubungan menggunakan alat ukur FMPS dan IPK yang dilaporkan sendiri. Meskipun demikian, penelitian Brumbaugh dkk. (2007) dilakukan terhadap 41 mahasiswa yang pada umumnya didominasi oleh mahasiswa Kaukasia, sementara penelitian ini ditujukan pada 86 mahasiswa berbakat intelektual dengan dominasi mahasiswa Asia. Diasumsikan bahwa tidak terdapat hubungan yang signifikan karena perfeksionisme yang dihayati belum tentu merefleksikan perilaku perfeksionisme pada kehidupan akademiknya dalam sampel penelitian ini, sehingga dampaknya pada prestasi akademik pun tidak dapat dilihat (Brumbaugh dkk., 2007).

Penelitian ini menunjukkan hasil yang sama dengan beberapa penelitian sebelumnya terkait hubungan 
perfeksionisme maladaptif dan prestasi akademik. Meskipun demikian, responden dari penelitian terdahulu bukan merupakan mahasiswa berbakat intelektual, sehingga belum dapat terjelaskan dinamika yang terjadi selain besarnya pengaruh yang dimiliki oleh perfeksionisme terhadap prestasi akademik. Nounopoulos dkk. (2006) menemukan bahwa mahasiswa pada umumnya dengan perfeksionisme maladaptif melihat kesenjangan antara standar diri yang ditetapkan dengan performa yang dipersepsi oleh dirinya. Hal tersebut membuat kepercayaan diri mahasiswa dalam bidang akademik menjadi menurun. Akibatnya, mahasiswa mengurangi usahanya dalam bidang akademik yang kemudian membuat capaian IPK-nya menjadi rendah. Belum terjelaskan apakah dinamika yang sama terjadi pada mahasiswa berbakat intelektual. Oleh karena itu, tahap berikutnya pada pendekatan kualitatif dilakukan untuk dapat menjelaskan dinamika yang terjadi antara kedua variabel pada mahasiswa berbakat intelektual.

Berikut ini akan dibahas mengenai hasil studi kualitatif yang dilakukan terhadap 8 orang mahasiswa berbakat intelektual dengan karakteristik nilai ekstrem pada perfeksionisme maladaptif dan prestasi akademik yang dipilih dari 86 responden di tahap studi kuantitatif. Data 4 mahasiswa berbakat intelektual dengan nilai perfeksionisme maladaptif yang rendah dan prestasi akademik yang tinggi serta 4 mahasiswa berbakat intelektual dengan nilai perfeksionisme maladaptif yang tinggi dan prestasi akademik yang rendah dapat dilihat pada Tabel 3.

Tabel 3. Data Responden Penelitian Tahap Kualitatif

\begin{tabular}{llllll}
\hline $\begin{array}{l}\text { Perfeksionisme } \\
\text { maladaptif } \\
\text { (FMPS) }\end{array}$ & $\begin{array}{l}\text { Prestasi } \\
\text { Akademik } \\
\text { (IPK) }\end{array}$ & Kode & JK & Usia & $\begin{array}{l}\text { Program } \\
\text { Akselerasi }\end{array}$ \\
\hline Rendah & Tinggi & R1 & P & 19 & SMP \\
& & R2 & L & 21 & Tidak \\
& & R3 & P & 21 & Tidak \\
& & R4 & P & 19 & SMP \\
Tinggi & Rendah & R5 & P & 19 & Tidak \\
& & R6 & L & 18 & Tidak \\
& & R7 & L & 17 & SMA \\
& & R8 & L & 20 & Tidak \\
\hline
\end{tabular}

Pendekatan studi kasus digunakan untuk menganalisis hasil wawancara pada kedua kelompok prestasi akademik. Pemilahan mahasiswa berbakat intelektual pada prestasi akademik tinggi dan rendah ditujukan untuk menemukan tema-tema yang menunjukkan kesamaan dan perbedaan dari kedua kelompok responden yang dimiliki. Persamaan dan perbedaan akan dapat memberikan penjelasan kekhasan hubungan perfeksionisme maladaptif dengan prestasi akademik pada mahasiswa berbakat intelektual.

Tabel 4. Tema pada Kelompok Perfeksionis Rendah Prestasi Akademik Tinggi dan Kelompok Perfeksionis Tinggi - Prestasi Akademik Rendah Persamaan Perbedaan

1. Perfeksionisme
memiliki
pengaruh
negatif
terhadap
prestasi
akademik.

1. Mahasiswa berbakat intelektual yang memiliki perfeksionisme maladaptif yang rendah menghayati dirinya tidak perfeksionis atau sudah tidak perfeksionis lagi, sementara mahasiswa berbakat intelektual dengan perfeksionisme maladaptif tinggi menghayati dirinya perfeksionis.

2. Mahasiswa berbakat intelektual dengan prestasi tinggi dapat menerima batasan diri dan lebih realistis dalam menilai kemampuan dirinya untuk mencapai prestasi akademik, sementara mahasiswa berbakat intelektual dengan prestasi rendah memiliki standar diri yang tinggi yang menyulitkan dirinya untuk mencapai prestasi tinggi sejak masuk perkuliahan.

3. Mahasiswa berbakat intelektual dengan prestasi tinggi memiliki sikap lebih realistis sehingga memilih mata kuliah yang dikuasai dan berprestasi di mata kuliah tersebut sehingga pada akhirnya membantunya dalam mencapai prestasi akademik yang tinggi. Sementara itu, mahasiswa berbakat intelektual dengan prestasi rendah 
memiliki standar diri

yang membuat mereka

berperilaku yang

kontraproduktif

terhadap kegiatan

akademik.

Berdasarkan tema-tema di atas, dapat dilihat bahwa mahasiswa berbakat intelektual dengan perfeksionisme maladaptif rendah maupun tinggi sepakat perfeksionisme memiliki dampak yang negatif terhadap prestasi akademik yang mereka miliki. Hal ini sejalan dengan hasil kuantitatif yang diperoleh pada tahap sebelumnya, yaitu perfeksionisme maladaptif memiliki pengaruh negatif terhadap prestasi akademik. Mahasiswa berbakat intelektual pada saat pendidikan di sekolah dasar atau menengah menghayati perfeksionisme membantu mereka untuk mencapai prestasi yang tinggi. Namun ketika di perguruan tinggi, kecenderungan untuk perfeksionis dalam semua mata kuliah yang ada membuat mereka menjadi tidak berhasil mencapai prestasi yang diharapkan. Oleh karena itu, mahasiswa berbakat intelektual dengan prestasi yang tinggi, menghayati dirinya tidak perfeksionis atau sudah tidak lagi perfeksionis karena mereka hanya berusaha sempurna pada mata kuliah tertentu saja.

Perfeksionisme yang berpengaruh negatif pada prestasi akademik, dapat dilihat ketika perfeksionisme ini berlaku secara maladaptif. Sementara perfeksionisme yang berlaku secara adaptif tidak memiliki pengaruh yang negatif terhadap prestasi akademik mahasiswa berbakat intelektual (Madigan, 2019). Tema yang muncul di kualitatif mendukung hasil penelitian dari Madigan (2019), di mana mahasiswa berbakat intelektual dengan perfeksionisme maladaptif rendah pada dasarnya merupakan mahasiswa berbakat intelektual perfeksionisme adaptif. Hal ini karena mereka tetap memiliki kecenderungan berprestasi yang tinggi, hanya mereka mengenali batasan dirinya dan hanya menetapkan prestasi tertinggi pada mata kuliah yang dikuasainya. Sejalan dengan penelitian sebelumnya (Fong \& Cai, 2019) yang mengatakan perfeksionisme adaptif yang dapat memahami dengan jelas batasan dirinya akan lebih dapat bersikap adaptif terhadap tujuan yang dicapaimya.

Pada mahasiswa berbakat intelektual, perfeksionisme maladaptif berpengaruh negatif pada prestasi akademik karena mahasiswa berbakat intelektual dengan perfeksionisme maladaptif tinggi sulit untuk mengakui batasan dirinya, dan tetap mempertahankan standar diri yang tinggi meski sebenarnya kesulitan untuk mencapainya. Mahasiswa berbakat intelektual, yang memiliki kemampuan berpikir yang lebih baik dari kebanyakan temannya dan memiliki pengalaman keberhasilan yang baik sejak masa kecil, tentu sulit untuk mengakui dirinya memiliki keterbatasan. Mereka memiliki pengakuan terhadap dirinya yang perlu dipertahankan. Parker (2000) mengatakan bahwa perfeksionisme maladaptif pada mahasiswa berbakat intelektual ditujukan untuk mendapatkan pengakuan dari orang lain dan tidak memberi kesempatan pada dirinya untuk merasa puas dengan pencapaiannya, sementara mahasiswa dengan perfeksionisme adaptif akan mampu beradaptasi ketika mengalami kegagalan karena didasari keinginan atau hasrat untuk memaksimalkan potensi diri dan bentuk aktualisasi.

Keinginan mahasiswa berbakat intelektual, dengan perfeksionisme maladaptif yang tinggi untuk mencapai prestasi yang tinggi, sulit dicapai karena mereka memiliki pemikiran yang negatif atau melakukan tindakan yang kontraproduktif dalam kegiatan akademik ketika memiliki eveluasi diri yang buruk terhadap capaian dirinya. Data wawancara menunjukkan bahwa mahasiswa berbakat intelektual dengan perfeksionisme maladaptif tinggi lebih fokus pada proses pembuatan dan persiapan tugas daripada penyelesaian, sehingga akhirnya tugasnya tidak dikumpulkan atau dikumpulkan secara tidak lengkap. Ketika mereka mendapatkan nilai yang tidak sesuai harapan, mereka sulit tidur atau berpikiran negatif tentang hasil belajarnya yang kurang di mata kuliah tertentu sehingga tidak bisa masuk kelas pada keesokan harinya, tidak bisa berkonsentrasi dengan tugasnya, atau mengerjakan ujiannya. Sementara itu, mahasiswa berbakat intelektual dengan perfeksionisme maladaptif rendah sudah lebih mampu menerima jika mendapatkan nilai ujian yang tidak sesuai, terutama untuk mata kuliah yang sudah mereka putuskan untuk diabaikan. Berdasarkan wawancara, diketahui mahasiswa berbakat intelektual kelompok prestasi tinggi tidak keberatan dengan adanya mata kuliah yang tidak mendapat nilai A. Namun, secara umum, IPK mereka tetap masuk kategori pujian. Hal berbeda dihayati oleh kelompok mahasiswa berbakat intelektual kelompok prestasi akademik rendah. Seluruh kondisi tersebut membuat mahasiswa berbakat intelektual dengan perfeksionisme maladaptif sulit untuk mencapai prestasi akademik tinggi yang diharapkannya.

\section{SIMPULAN}

Berdasarkan penelitian campuran sekuensial yang telah dilakukan, dapat disimpulkan bahwa perfeksionisme maladaptif yang tinggi pada mahasiswa berbakat intelektual akan berdampak pada rendahnya prestasi akademiknya, dan begitu pula sebaliknya. Penjelasan tentang dinamika yang khas pada mahasiswa berbakat intelektual pada kedua variabel diperoleh dari simpulan tahap kedua penelitian kualitatif. Berdasarkan hasil riset, diperoleh kesimpulan bahwa perfeksionisme maladaptif pada mahasiswa berbakat intelektual memiliki pengaruh negatif pada prestasi akademik karena dua hal. Pertama, perfeksionisme yang dimiliki sangat dominan, sehingga mahasiswa berbakat intelektual sulit untuk 
menerima keterbatasan kemampuan dirinya. Kedua, sikap sulit untuk menerima bahwa dirinya dapat melakukan kesalahan atau mengalami kegagalan membuat mereka tidak dapat berperilaku produktif dalam melakukan kegiatan akademik.

Hasil penelitian yang diperoleh memiliki implikasi bagi psikolog dan pihak perguruan tinggi perlu waspada akan adanya kecenderungan perfeksionisme maladaptif pada mahasiswa berbakat dengan prestasi akademik yang rendah, dan dianjurkan melakukan konseling untuk mengatasinya. Mahasiswa berbakat juga memiliki kesadaran kecenderungan perfeksionisme maladaptif dan mengetahui dampaknya terhadap prestasi akademik, sehingga dapat menghindarinya dengan pola pikir dan perilaku yang rasional. Pada penelitian selanjutnya, hasil penelitian kualitatif dapat diuji secara kuantitatif, di mana kemampuan untuk dapat menerima kesalahan atau menerima keterbatasan dirinya dapat diuji sebagai variabel mediator atau variabel moderator.

\section{KELAYAKAN ETIK}

Penelitian ini telah lolos kelayakan etik dari Komisi Etik Fakultas Psikologi Universitas Indonesia no. 316/F.Psi.KomiteEtik/PDP.04.00/2017

\section{DAFTAR PUSTAKA}

Amanda, D., Siaputra, I. B., \& Lasmono, H. K. (2012). Academic procrastination and perfectionism (adaptive and maladaptive). ANIMA Indonesian Psychological Journal, 27(2), 117-126.

Ananda, N. Y., \& Mastuti, E. (2013). Pengaruh perfeksionisme terhadap prokrastinasi akademik pada siswa program akselerasi. Jurnal Psikologi Pendidikan Dan Perkembangan, 2(3), 226-231.

Blankstein, K. R., Dunkley, D. M., \& Wilson, J. (2008). Evaluative concerns and personal standards perfectionism: Self-esteem as a mediator and moderator of relations with personal and academic needs and estimated GPA. Current Psychology, 27, 29-61. https://doi.org/10.1007/s12144-008-9022-1

Brumbaugh, J., Lepsik, R., \& Olinger, C. (2007). The relationship between GPA and perfectionism. Undergraduate Research Journal for the Human Sciences, 6 .

Callard-Szulgit, R. (2012). Perfectionism and gifted children (2nd ed.). Maryland: Rowman \& Littefield Education.

Chan, D. W. (2010). Healthy and unhealthy perfectionists among academically gifted Chinese students in Hong Kong: Do different classification schemes make a difference? Roeper Review, 32(2), 88-97. https://doi.org/10.1080/02783191003587876

Creswell, J. W., \& Clark, V. L. P. (2011). Designing and conducting mixed methods research. California:
SAGE Publication Inc.

Cross, J. R., \& Cross, T. L. (2015). Clinical and mental health issues in counseling the gifted individual. Journal of Counseling and Development, 93(2), 163172. 6676.2015.00192.x https://doi.org/10.1002/j.1556-

Davis, G. A., Rimm, S. B., \& Siegle, D. (2014). Education of the gifted and talented (6th ed.). New Jersey: Pearson New International Edition.

Eklund, K., Tanner, N., Stoll, K., \& Anway, L. (2015). Identifying emotional and behavioral risk among gifted and nongifted children: A multi-gate, multiinformant approach. School Psychology Quarterly, 30(2), 197-211. https://doi.org/10.1037/spq0000080

Elion, A. A., Wang, K. T., Slaney, R. B., \& French, B. H. (2012). Perfectionism in African American students: Relationship to racial identity, GPA, self-esteem, and depression. Cultural Diversity and Ethnic Minority Psychology, 18(2), 118-127. https://doi.org/10.1037/a0026491

Fong, R. W., \& Cai, Y. (2019). Perfectionism, selfcompassion and test-related hope in Chinese primary school students. The Asia-Pacific Education Researcher, 28(4), 293-302. https://doi.org/10.1007/s40299-019-00466-0

Fong, R. W., \& Yuen, M. (2014). Perfectionism and Chinese gifted learners. Roeper Review, 36(2), 81-91. https://doi.org/10.1080/02783193.2014.884202

Frost, R. O., Marten, P., Lahart, C., \& Rosenblate, R. (1990). The dimensions of perfectionism. Cognitive Therapy and Research, 14(5), 449-468. https://doi.org/10.1007/BF01172967

Gallagher, J. J. (2015). Psychology, psychologists, and gifted students. Journal for the Education of the Gifted, 38(1), 6-17. https://doi.org/10.1177/0162353214565548

Gunawinata, V. A. R., Nanik, \& Lasmono, H. K. (2008). Perfeksionisme, prokrastinasi akademik, dan penyelesaian skripsi mahasiswa. ANIMA Indonesian Psychological Journal, 23(3), 256-276.

Hébert, T. P. (2011). Understanding the social and emotional lives of gifted students. Roeper Review, 36(4), https://doi.org/10.1080/02783193.2014.945144

Kerr, B. (Ed.). (2009). Encyclopedia of giftedness, creativity, and talent (Vols. 1-2). California: SAGE Publication Inc.

Kemendikbud, Permendikbud Nomor 3 Tahun 2020. $\begin{array}{llll}\text { (n.d). } & 17 & \text { Februari } & 2020\end{array}$ http://lldikti3.ristekdikti.go.id/v6/wpcontent/uploads/2020/01/Permendikbud-Nomor-3Tahun-2020.pdf

Madigan, D. J. (2019). A meta-analysis of perfectionism and academic achievement. Educational Psychology Review, 31(4), 967-989. https://doi.org/10.1007/s10648-019-09484-2

Neihart, M., Reis, S. M., Robinson, N. M., \& Moon, S. 
M. (Eds.). (2002). The social and emotional development of gifted children: What do we know? Waco: Prufrock Press, Inc.

Nounopoulos, A., Ashby, J. S., \& Gilman, R. (2006). Coping resources, perfectionism, and academic performance among adolescents. Psychology in the Schools, 43(5), 613-622. https://doi.org/10.1002/pits.20167

Ormrod, J. E., Anderman, E. M., \& Anderman, L. H. (2017). Educational psychology: Developing learners (9th ed.). Boston: Pearson Education Limited.

Parker, W. D. (2000). Healthy perfectionism in the gifted. Journal of Secondary Gifted Education, 11(4), 173182.

Renzulli, J. S. (1986). The three-ring conception of giftednesss: A developmental model for creative productivity. Conceptions of Giftedness (2nd ed.), 246-279. Cambridge University Press. https://doi.org/10.1017/CBO9780511610455.015

Renzulli, J. S., \& Reis, S. M. (1985). The schoolwide enrichment model: A comprehensive plan for educational excellence. Mansfield Center, CT: Creative Learning Press.

Rimm, S. (2006). When gifted students underachieve: What you can do about it. Waco, Texas: Prufrock Press, Inc.

Schuler, P. A. (2000). Perfectionism and the gifted adolescent. Journal of Secondary Gifted Education, 11(4).

Sirois, F. M., Monforton, J., \& Simpson, M. (2010). "If only I had done better": Perfectionism and the functionality of counterfactual thinking. Personality and Social Psychology Bulletin, 36(12), 1675-1692. https://doi.org/10.1177/0146167210387614

Steiner, H. H., \& Carr, M. (2003). Cognitive development in gifted children: Toward a more precise understanding of emerging differences in intelligence. Educational Psychology Review, 15(3), 215-246. https://doi.org/10.1023/A:1024636317011

Sternberg, R. J., \& Davidson, J. E. (Eds.). (2005). Conceptions of giftedness (2nd ed.). New York: Cambridge University Press.

Sternberg, R. J., Jarvin, L., \& Grigorenko, E. L. (2011). Explorations in giftedness. New York: Cambridge University https://doi.org/10.1017/CBO9780511778049

Stoeber, J. (2018). The psychology of perfectionism: Theory, research, applications. New York: Routledge.

Stornelli, D., Flett, G. L., \& Hewitt, P. L. (2009). Perfectionism, achievement, and affect in children: A comparison of students from gifted, arts, and regular programs. Canadian Journal of School Psychology, 24(4), 267-283. https://doi.org/10.1177/0829573509342392

VanTassel-Baska, J. L., Cross, T. L., \& Olenchak, F. R. (2009). Social-emotional curriculum with gifted and talented students. Waco: Prufrock Press, Inc. 